\title{
Agronomic performance and soil chemical attributes in a banana tree orchard fertigated with humic substances ${ }^{1}$
}

\author{
Diego Magalhães de $\mathrm{Melo}^{2}$, Eugênio Ferreira Coelho \\ Ana Lúcia Borges ${ }^{3}$, Bruno Laecio da Silva Pereira² ${ }^{2}$ Marcos Sousa Campos ${ }^{2}$
}

\section{ABSTRACT}

Fertigation with humic substances products has been adopted in commercial banana tree plantations. However, there are few studies on the procedure to confirm its technical feasibility. This study aimed at assessing the effects of fertigation with humic substances on the chemical attributes of a Dystric Densic Xantic Ferralsol cultivated with the 'BRS Princesa' banana tree cultivar and on the agronomic performance of the orchard. The experiment was conducted using a randomized blocks design, with six treatments and four replications. Treatments consisted of a monthly application of humic substances doses based on the commercially recommended reference dose for the banana plantation $\left(12.09 \mathrm{~kg} \mathrm{ha}^{-1}\right.$ cycle $\left.^{-1}\right)$. The doses used were equivalent to percentages of the reference dose $(100 \%$, $150 \%, 200 \%, 250 \%$ and $300 \%$ ), in addition to the control. No significant effects of the fertigation with humic substances that could justify the use of the product at the doses assessed were observed on the soil chemical attributes, banana growth and yield.

KEYWORDS: Musa sp.; soil conditioner; drip irrigation.

\section{INTRODUCTION}

Humic substances are the primary constituents of the soil organic matter, corresponding generically to the final product of organic waste decomposition in nature. They exhibit high stability, reactivity and persistence in the soil, besides being considered recalcitrant to biodegradation (Santos et al. 2008). Concerning their chemical nature, they display a high complexity and structural diversity, and are composed of humin, as well as humic and fulvic acids (Primo et al. 2011).

These carbon-rich organic materials exert a series of beneficial effects on soil attributes, including

\section{RESUMO}

Desempenho agronômico e atributos químicos do solo em pomar de bananeira fertirrigado com substâncias húmicas

A fertirrigação com produtos à base de substâncias húmicas vem sendo adotada em plantios comerciais de bananeiras. No entanto, tal procedimento ainda carece de mais estudos para comprovar sua viabilidade técnica. Objetivou-se avaliar os efeitos da fertirrigação com substâncias húmicas nos atributos químicos de um Latossolo Amarelo distrocoeso cultivado com bananeira 'BRS Princesa' e no desempenho agronômico do pomar. O experimento foi conduzido em delineamento de blocos casualizados, com seis tratamentos e quatro repetições. Os tratamentos consistiram da aplicação mensal de doses de substâncias húmicas, calculadas a partir da dose de referência $\left(12,09 \mathrm{~kg} \mathrm{ha}^{-1}\right.$ ciclo $\left.^{-1}\right)$ recomendada comercialmente para o cultivo da bananeira. As doses utilizadas foram equivalentes a porcentagens da dose de referência $(100 \%, 150 \%, 200 \%, 250 \%$ e $300 \%$ ), além da testemunha. Não foram observados efeitos significativos da fertirrigação com substâncias húmicas que justificassem o emprego do insumo nas doses avaliadas sobre os atributos químicos do solo, crescimento e produção das bananeiras.

PALAVRAS-CHAVE: Musa sp.; condicionador de solo; irrigação localizada.

positive effects on water storage capacity, soil aggregate formation and maintenance, cationic exchange capacity and nutrient availability (Mbagwu \& Piccolo 1989, Seyedbagheri 2010, Selim \& Mosa 2012, Baldotto \& Baldotto 2014, Caron et al. 2015). Humic substances may also stimulate the plant physiology, depending on the species and humic substance characteristics, such as concentration, molecular weight, organic acid structure and material of origin (Lodhi et al. 2013, Muscolo et al. 2013, Zandonadi et al. 2013, Canellas \& Olivares 2014, Caron et al. 2015).

Mahmoud \& Hafez (2010) and Selim et al. (2010) obtained encouraging results with humic

1. Manuscript received in Jul./2016 and accepted for publication in Dec./2016 (http://dx.doi.org/10.1590/1983-40632016v4642222).

2. Universidade Federal do Recôncavo da Bahia, Núcleo de Engenharia de Água e Solo, Cruz das Almas, BA, Brazil.

E-mails: engdmmelo@gmail.com, brunolaecio_3@hotmail.com, marcossc_ufersa@hotmail.com.

3. Empresa Brasileira de Pesquisa Agropecuária (Embrapa Mandioca e Fruticultura Tropical), Cruz das Almas, BA, Brazil.

E-mails: eugenio.coelho@embrapa.br, ana.borges@embrapa.com.br. 
substances fertigation of potato crops in sandy soil. These authors reported positive effects on the chemical attributes of the sandy soil, including $\mathrm{K}$ content, and reduced leaching with the use of humic substances in association with mineral fertilization. Under controlled conditions, Arjumend et al. (2015) observed positive effects on $\mathrm{N}, \mathrm{P}, \mathrm{K}$ and organic matter content in pots filled with clay and silty-clay soils cultivated with wheat. In addition, Bezerra et al. (2015) reported a greater P availability after the application of humic substances to pots containing Neossol and Argissol cultivated with sugarcane.

In relation to the banana tree, Nomura et al. (2012) and Russo et al. (1995) reported positive results after applying these substances to seedlings grown under controlled conditions. Coelho et al. (2016) studied the drip irrigation of humic substances (doses up to $42.42 \mathrm{~L} \mathrm{ha}^{-1}$ cycle $^{-1}$ ), in a Dystric Densic Xantic Ferralsol cultivated with 'BRS Princesa' banana trees, and found no effects on the plant performance or soil physical-hydraulic attributes, during the first production cycle of the orchard.

According to López (2005), an important issue regarding the application of humic substances in commercial crops is that the high costs involved mean that the recommended doses are low, and are therefore frequently insufficient to improve the soil attributes and crop performance. Jones et al. (2007), Hartz \& Bottoms (2010) and Little et al. (2014) found no effects that would justify the use of these substances at the doses and conditions studied.

There is little information about the effects of fertigation with these organic substances on the chemical attributes of a Dystric Densic Xantic Ferralsol and on the performance of banana trees, in consecutive production cycles.

This study aimed at assessing the direct effects of fertigation with humic substances, using a microsprinkler system, on the chemical attributes of a Dystric Densic Xantic Ferralsol cultivated with 'BRS Princesa' banana trees, in addition to evaluating the agronomic performance of the orchard.

\section{MATERIAL AND METHODS}

The experiment was conducted at the experimental field of the Centro Nacional de Pesquisa de Mandioca e Fruticultura Tropical (12 $40^{\prime} 19^{\prime \prime}$, $39^{\circ} 06^{\prime} 23^{\prime \prime} \mathrm{W}$ and altitude of $225 \mathrm{~m}$ ), in Cruz das Almas, Bahia State, Brazil. The local climate is classified as hot humid tropical (Aw to Am), according to the Köppen-Geiger classification. Annual average records for the area have been collected in the last five years (2011-2015) at its automatic weather station, showing maximum, minimum and average temperatures, relative humidity and accumulated rainfall of $29.02{ }^{\circ} \mathrm{C}, 20.8{ }^{\circ} \mathrm{C}, 23.9^{\circ} \mathrm{C}, 82.8 \%$ and $1,069 \mathrm{~mm}$ year $^{-1}$, respectively.

The experiment was conducted between 2012 and 2015, during two production cycles of a 'BRS Princesa' banana tree plantation. The first production cycle was considered the time between the seedling transplantation and the first harvest, while the second cycle comprised the time between the first and second harvest. The orchard was cultivated in a soil classified as Dystric Densic Xantic Ferralsol, considering the world reference base for soil resources (IUSS Working Group WRB 2014), or Latossolo Amarelo distrocoeso, according to the Brazilian soil classification (Santos et al. 2013).

The physical-hydraulic and chemical attributes of the soil in the experimental area were determined before the transplantation of banana seedlings. The soil was sampled at two depths (0-0.20 m and 0.20$0.40 \mathrm{~m}$ ), with four repetitions. Only the average values were considered for the initial characterization of the soil attributes (Table 1).

The experimental area was prepared before the micropropagated 'BRS Princesa' seedlings were transplanted (October 20, 2012), with spacing of $2.0 \mathrm{~m} \times 2.5 \mathrm{~m}$. The planting holes had $0.5 \mathrm{~m} \times 0.5 \mathrm{~m}$ and depth of $0.30 \mathrm{~m}$. Fertilizer was applied to each hole using $12 \mathrm{~L}$ of hardened cow manure, $70 \mathrm{~g}$ of a micronutrient mixture of FTE BR 12 and $150 \mathrm{~g}$ of single superphosphate. There was no need for liming.

The control of invasive plants was conducted manually through weeding, thinning and defoliation (Alves et al. 2004).

Microsprinkling was the irrigation system employed. The emitters used a self-compensating pressure mechanism, flow of $54 \mathrm{~L} \mathrm{~h}^{-1}$ and action radius of around $2.15 \mathrm{~m}$. The microsprinklers were distributed to irrigate four plants per emitter. The system used an operating pressure of 2.0-2.2 bars. The fertilizers and humic substances applied during the experiment were injected into the hydraulic network by a dismountable injector piston pump with a regulatable flow rate of up to $60 \mathrm{~L} \mathrm{~h}^{-1}$.

Artificial water replacements were determined based on the crop evapotranspiration obtained by the 
Table 1. Analysis of the physical-hydraulic and chemical attributes of the soil before transplanting the banana seedlings.

\begin{tabular}{|c|c|c|c|c|c|c|c|c|c|c|c|c|}
\hline \multicolumn{13}{|c|}{ Soil physical properties } \\
\hline Horizon & \multicolumn{3}{|c|}{ Porosity (\%) } & $\mathrm{Sd}$ & \multicolumn{3}{|c|}{ Granulometry $\left(\mathrm{g} \mathrm{kg}^{-1}\right)$} & \multirow{2}{*}{\multicolumn{5}{|c|}{$\frac{\text { Textural classification }}{\text { (Tyne) }}$}} \\
\hline Depth $(\mathrm{m})$ & Total & Macro & Micro & $\mathrm{g} \mathrm{cm}^{-3}$ & Total sand & Silt & Clay & \multicolumn{2}{|c|}{ (Type) } & & & \\
\hline $0.00-0.20$ & 30.49 & 9.9 & 20.59 & 1.76 & 732 & 87 & 181 & \multicolumn{5}{|c|}{ Sandy loam } \\
\hline $0.20-0.40$ & 27.53 & 5.25 & 22.28 & 1.79 & 629 & 68 & 303 & \multicolumn{5}{|c|}{ Sandy clay } \\
\hline \multicolumn{13}{|c|}{ Soil hydraulical properties } \\
\hline Horizon & \multicolumn{5}{|c|}{ Gravimetric moisture water retention (\%) by tension (atm) } & \multicolumn{3}{|c|}{ Available water } & \multicolumn{4}{|c|}{ Saturated hydraulic conductivity } \\
\hline Depth (m) & 0.1 & 0.33 & 1 & 3 & 15 & \multicolumn{3}{|c|}{$\%$} & \multicolumn{4}{|c|}{$\mathrm{mm} \mathrm{h}^{-1}$} \\
\hline $0.00-0.20$ & 10.318 & 9.588 & 9.43 & 9.057 & 7.824 & \multicolumn{3}{|c|}{2.494} & \multicolumn{4}{|c|}{3.847} \\
\hline $0.20-0.40$ & 10.72 & 9.733 & 9.023 & 8.562 & 7.813 & \multicolumn{3}{|c|}{2.907} & \multicolumn{4}{|c|}{3.3} \\
\hline \multicolumn{13}{|c|}{ Soil chemical properties } \\
\hline Horizon & $\mathrm{pH}$ & $\mathrm{P}^{(1)}$ & $\mathrm{K}^{(1)}$ & $\mathrm{Ca}^{(2)}$ & $\mathrm{Mg}^{(2)}$ & $\mathrm{Al}^{(2)}$ & $\mathrm{Na}^{(1)}$ & $\mathrm{H}+\mathrm{Al}$ & TEB & CEC & $\mathrm{V}$ & $\mathrm{OM}^{(3)}$ \\
\hline Depth (m) & $\mathrm{H}_{2} \mathrm{O}$ & $\mathrm{mg} \mathrm{dm}^{-3}$ & & & 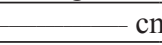 & $10 l_{\mathrm{c}} \mathrm{dr}$ & & & & & $\%$ & $\mathrm{~g} \mathrm{~kg}^{-1}$ \\
\hline $0.00-0.20$ & 6.7 & 16 & 0.1 & 2.5 & 0.9 & 0 & 0.01 & 0.7 & 4 & 4.3 & 84 & 7.0 \\
\hline $0.20-0.40$ & 6.0 & 6 & 0.1 & 1.7 & 0.7 & 0 & 0.01 & 1.4 & 3 & 3.9 & 64 & 5.9 \\
\hline
\end{tabular}

SHC: saturated hydraulic conductivity; TEB: total exchangeable bases; CEC: cation exchange capacity; V: base saturation; OM: organic matter. ${ }^{(1)}$ Mehlich-1 extraction;

${ }^{(2)} \mathrm{KCl} 1 \mathrm{M}$ extraction; ${ }^{(3)}$ modified Walkley \& Black method (Silva et al. 1999).

product of the reference evapotranspiration, which, in turn, was calculated using the modified PenmanMonteith equation (Allen et al. 1998) and crop coefficients described by Coelho et al. (2006). The analysis of the water used in the experiment, collected during the dry season, is presented in Table 2.

Fertigations were initiated following the emergence of new leaves (around 30 days after

Table 2. Analysis of the chemical attributes of the irrigation water used in the experiment.

\begin{tabular}{lcr}
\hline Parameters analyzed ${ }^{(1)}$ & Unit & Result \\
\hline Electrical conductivity & $\mathrm{dS} \mathrm{m}^{-1}$ & 0.65 \\
$\mathrm{Ca}$ & $\mathrm{mg} \mathrm{L}^{-1}$ & 28.00 \\
$\mathrm{Mg}$ & $\mathrm{mg} \mathrm{L}^{-1}$ & 17.00 \\
$\mathrm{~K}$ & $\mathrm{mg} \mathrm{L}^{-1}$ & 0.80 \\
$\mathrm{Na}$ & $\mathrm{mg} \mathrm{L}^{-1}$ & 100.00 \\
$\mathrm{pH}$ & - & 7.60 \\
Sodium adsorption ratio & - & 3.60 \\
Total hardness $\left(\mathrm{CaCO}_{3}\right)$ & $\mathrm{mg} \mathrm{L}^{-1}$ & 140.00 \\
Irrigation water quality classification & - & $\mathrm{C}_{2} \mathrm{~S}_{1}$ \\
\hline (1) Analysis of the water samples collected at the hottest and driest periods.
\end{tabular}

transplanting), with weekly doses of $\mathrm{N}$ and $\mathrm{K}$ and quarterly doses of $\mathrm{P}$, in the form of urea, potassium chloride $(\mathrm{KCl})$ and monoammonium phosphate, respectively. The amount of fertilizer applied was calculated based on the soil analysis and recommendations by Borges \& Souza (2009). The amount of fertilizers applied is presented in Table 3.

A randomized blocks design was adopted, with six treatments, four replications and eight plants per experimental unit $\left(40 \mathrm{~m}^{2}\right)$, six of which were used. Treatments consisted of the monthly application of humic substances doses, which corresponded to the fractions of a reference dose of $24.18 \mathrm{~kg} \mathrm{ha}^{-1}$. Reference doses were calculated for the two orchard production cycles, based on the commercial recommendations of the product for fertigation $\left(12.09 \mathrm{~kg} \mathrm{ha}^{-1} \mathrm{cycle}^{-1}\right)$. The doses used were equivalent to the following reference percentages: T1: $100 \%$; T2: $150 \%$; T3: $200 \%$; T4: $250 \%$; and T5: $300 \%$, in addition to the control (T6: $0 \%$ ).

The product used during the experiment contained humic substances extracted from a

Table 3. Sources of nutrients, nutrient concentration in fertilizers, frequency of application and dose applied.

\begin{tabular}{|c|c|c|c|c|}
\hline $\begin{array}{c}\text { Source } \\
\text { (Fertilizer) }\end{array}$ & $\begin{array}{c}\text { Nutrient } \\
\text { (Element) }\end{array}$ & $\begin{array}{c}\text { Concentration }^{(1)} \\
\mathrm{g} \mathrm{kg}^{-1}\end{array}$ & $\begin{array}{c}\text { Frequency } \\
\text { (Interval) }\end{array}$ & $\begin{array}{c}\text { Amount }^{(2)} \\
\mathrm{kg} \mathrm{ha}^{-1} \text { cycle }^{-1}\end{array}$ \\
\hline Urea & $\mathrm{N}$ & 450 & Weekly & 445 \\
\hline MAP & $\mathrm{P}_{2} \mathrm{O}_{5}$ & 480 & Quarterly & 150 \\
\hline $\mathrm{KCl}$ & $\mathrm{K}_{2} \mathrm{O}$ & 500 & Weekly & 600 \\
\hline
\end{tabular}

(1) Approximate concentration on the label of the product, according to the manufacturer; ${ }^{(2)}$ amount of fertilizers used in both cropping cycles, based on the recommendations by Borges \& Souza (2009). 
mineraloid rich in organic carbon known as leonardite, which exhibited the following specifications: humic acids $=100 \mathrm{~g} \mathrm{~kg}^{-1}$; fulvic acids $=102 \mathrm{~g} \mathrm{~kg}^{-1}$; $\mathrm{K}=26.6 \mathrm{~g} \mathrm{~kg}^{-1}$; and density $=1.14 \mathrm{~kg} \mathrm{dm}^{-3}$.

The application of humic substances initiated at the end of December 2012, while the last dose was applied at the beginning of January 2015, totaling 25 applications, 14 of which were applied by the end of the first production cycle. Total and fractionated humic substances doses per treatment are shown in Table 4.

With respect to the assessment of the soil chemical attributes, samples were collected at the end of the second cycle, considering the total dose applied during the experiment. For purposes of soil sampling, a collection pattern was adopted, whereby samples were removed at $0.30 \mathrm{~m}$ from the pseudostem of one of the plants used in the experimental plot, at depths of $0.0-0.20 \mathrm{~m}$ and $0.20-0.40 \mathrm{~m}$, toward the irrigation emitters.

The following soil chemical attributes were assessed: $\mathrm{P}, \mathrm{K}, \mathrm{Ca}, \mathrm{Mg}$ and $\mathrm{Na}$ concentrations, as well as total exchangeable bases, cationic exchange capacity and base saturation (\%), following the methodology proposed by Embrapa (2011). The organic matter content was measured according to the modified Walkley \& Black method, as described by Silva et al. (1999).

Biometric data regarding the agronomic performance of banana plants were recorded at flowering and harvest. The following measures were taken at flowering: pseudostem height, considering the height from the ground to the apical meristem; pseudostem diameter, measured at $0.20 \mathrm{~m}$ from the ground; and number of viable leaves (completely open leaves with more than $2 / 3$ of limbs intact). At harvest, the following items were assessed: banana bunch mass, banana hand mass, banana stalk mass, number of hands per bunch, number of fruits per bunch, average fruit length, average fruit diameter, relative hand yield, relative bunch yield and time from transplanting to bunch harvest.

The banana bunch mass, banana hand mass and banana stalk mass were measured immediately after harvest, using a scale with an accuracy of $0.1 \mathrm{~kg}$. The average fruit length and average fruit diameter were obtained by assessing the median fruit from the second cluster of the bunch. The relative hand yield and relative bunch yield were respectively determined from the product of banana hand mass and banana bunch mass and orchard density (2,000 plants ha $\left.\mathrm{a}^{-1}\right)$, with the data recorded in $\mathrm{t} \mathrm{ha}^{-1}$.

The data obtained were statistically analyzed using the Sisvar 5.3 software. Analyses of variance (Anova) were conducted with the F-test. For significantly affected traits, a regression analysis (5\%) was performed to assess the mathematical adjustment and determine the optimal dose to affect the trait through humic substances fertigation.

\section{RESULTS AND DISCUSSION}

The analysis of variance $(\mathrm{p}<0.05)$ showed no significant effect of humic substances doses on the chemical attributes of the Dystric Densic Xantic Ferralsol, at the end of the experiment. The means per treatment and coefficient of variation per variable are shown in Table 5.

The absence of effects for the humic substances fertigation may be related to the doses applied, which

Table 4. Total and monthly doses of humic substances applied per treatment.

\begin{tabular}{lrrrrrr}
\hline \multirow{2}{*}{ Amount/Treatment } & \multicolumn{5}{c}{ Total humic substances doses applied during the experiment (\% of the recommended dose) } \\
\cline { 2 - 6 } & $100 \%$ & $150 \%$ & $200 \%$ & $250 \%$ & $300 \%$ & $0 \%$ \\
\hline Total applied $\left(\mathrm{L} \mathrm{ha}^{-1}\right)^{(1)}$ & 105.00 & 157.50 & 210.00 & 262.50 & 315.00 & 0.00 \\
Total applied $\left(\mathrm{kg} \mathrm{ha}^{-1}\right)$ & 24.18 & 36.27 & 48.36 & 60.45 & 72.54 & 0.00 \\
Total applied $\left(\mathrm{g} \mathrm{plant}^{-1}\right)^{(2)}$ & 12.09 & 18.14 & 24.18 & 30.23 & 36.27 & 0.00 \\
\hline \multirow{2}{*}{ Amount/Treatment } & \multicolumn{7}{c}{ Monthly humic substances doses applied (\% of the recommended dose) $)^{(3)}$} \\
\cline { 2 - 7 } & $100 \%$ & $150 \%$ & $200 \%$ & $250 \%$ & $300 \%$ & $0 \%$ \\
\hline Total applied $\left(\mathrm{L} \mathrm{ha}^{-1}\right)$ & 4.20 & 6.30 & 8.40 & 10.50 & 12.60 & 0.00 \\
Total applied $\left(\mathrm{kg} \mathrm{ha}^{-1}\right)$ & 0.97 & 1.45 & 1.93 & 2.42 & 2.90 & 0.00 \\
Total applied $\left(\mathrm{g} \mathrm{plant}^{-1}\right)$ & 0.48 & 0.73 & 0.97 & 1.21 & 1.45 & 0.00 \\
\hline
\end{tabular}

(1) Amount of humic substances, considering the commercial product with a density of $1.14 \mathrm{~kg} \mathrm{dm}^{-3}$ and the following chemical composition: humic acids (100 $\left.\mathrm{g} \mathrm{kg}^{-1}\right)$,

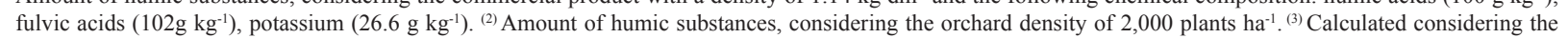
fractionation of the recommended dose $\left(24.18 \mathrm{~kg} \mathrm{ha}^{-1}\right)$ into 25 monthly doses applied starting in December 2012. 
may have been insufficient to promote beneficial effects on the soil. López (2005) reported that doses commercially recommended are often low and compromise the effect of humic substances, regardless of the quality of the product used in fertigation. This author related the experiences by Spanish producers with humic substances and explained that promising results were only found when the commercially recommended dose applied was concentrated. However, it is important to note that these humic substances are expensive.

The monthly fractionating of the doses may have attenuated the effect of the humic substances fertigation on the soil chemical attributes. Selim \& Mosa (2012) recorded positive effects on N, P, K, $\mathrm{Fe}, \mathrm{Mn}$ and $\mathrm{Zn}$ contents, in sandy soil cultivated with broccoli submitted to NPK drip fertigation with doses of humic substances. These authors used doses of $120 \mathrm{~L} \mathrm{ha}^{-1}$, which corresponded to $21.96 \mathrm{~kg} \mathrm{ha}^{-1}$ (humic acids + fulvic acids), fractionated into only three applications, during the four-month experiment. Zhang et al. (2013) also obtained positive results for soil nutrient content, in a Cambisol cultivated with apples. For two years, these authors incorporated a $247.5 \mathrm{~kg} \mathrm{ha}^{-1}$ year $^{-1}$ dose of humic substances containing $85 \%$ of humic acid and NPK.

The absence of humic substances effects was also reported by Hartz \& Bottoms (2010), who assessed the impact of applying different humic substances products extracted from leonardite, using doses of less than $5 \mathrm{~kg} \mathrm{ha}^{-1}$, in pots containing different types of soil cultivated with tomato or lettuce. Little et al. (2014) observed the absence of effects on the performance and nutrient absorption of forage legumes such as alfalfa. Jones et al. (2007) reported a similar result for the content and absorption of nutrients in pots containing wheat. Moreover, Lodhi et al. (2013) found differences in content among several humic substances products. These authors described variations in the response of the products tested, with respect to the performance of beans, corn and wheat.

In relation to the agronomic performance of the 'BRS Princesa' banana tree, there was also a lack of significant effects of the humic substances fertigation on growth and yield $(p>0.05)$. The only exception occurred for days from transplantation to bunch harvest, in the second production cycle, whose response fitted a quadratic model. The absence of positive effects from the humic substances fertigation on the soil chemical attributes may explain the lack of significant effects on the growth and yield properties of the orchard. This corroborates the findings by Coelho et al. (2016), who reported similar results for the agronomic performance of the 'BRS Princesa', during its first production cycle. The average values reported for the biometric variables are presented in Table 6.

Table 5. Average values of the soil chemical attributes per treatment and depth.

\begin{tabular}{|c|c|c|c|c|c|c|c|c|c|c|c|}
\hline Depth & Treatment $^{(1)}$ & \multirow{2}{*}{$\mathrm{pH}$} & $\mathrm{P}^{(2)}$ & $\mathrm{K}^{(2)}$ & $\mathrm{Ca}^{(3)}$ & $\mathrm{Mg}^{(3)}$ & $\mathrm{Na}^{(2)}$ & TEB & CEC & \multirow{2}{*}{$\begin{array}{c}\mathrm{V} \\
\%\end{array}$} & \multirow{2}{*}{$\begin{array}{l}\mathrm{OM}^{(4)} \\
\mathrm{g} \mathrm{kg}^{-1}\end{array}$} \\
\hline $\mathrm{m}$ & $\mathrm{kg} \mathrm{ha}^{-1}$ & & $\mathrm{mg} \mathrm{dm}^{-3}$ & \multicolumn{6}{|c|}{$-\mathrm{cmol}_{\mathrm{c}} \mathrm{dm}^{-3}$} & & \\
\hline $0.00-0.20$ & 0.00 & 6.88 & 20.00 & 0.17 & 2.23 & 1.05 & 0.43 & 3.91 & 4.33 & 90.00 & 12.75 \\
\hline $0.00-0.20$ & 24.18 & 6.55 & 16.00 & 0.16 & 1.67 & 0.92 & 0.69 & 3.03 & 3.71 & 81.00 & 9.50 \\
\hline $0.00-0.20$ & 36.27 & 6.55 & 15.00 & 0.19 & 1.87 & 0.95 & 0.67 & 3.27 & 3.94 & 82.00 & 9.50 \\
\hline $0.00-0.20$ & 48.36 & 6.85 & 23.00 & 0.19 & 2.58 & 1.26 & 0.35 & 4.40 & 4.75 & 91.00 & 14.50 \\
\hline $0.00-0.20$ & 60.45 & 6.83 & 34.00 & 0.22 & 2.22 & 1.08 & 0.50 & 3.80 & 4.30 & 88.00 & 12.00 \\
\hline $0.00-0.20$ & 72.54 & 7.03 & 25.00 & 0.22 & 2.19 & 1.11 & 0.32 & 3.77 & 4.09 & 92.00 & 12.50 \\
\hline CV (\%) & - & 4.37 & 57.74 & 31.54 & 20.86 & 24.24 & 92.72 & 17.83 & 12.89 & 12.76 & 34.43 \\
\hline Mean & - & 6.78 & 22.00 & 0.19 & 2.13 & 1.06 & 0.49 & 3.70 & 4.19 & 88.00 & 11.79 \\
\hline $0.20-0.40$ & 0.00 & 6.88 & 10.00 & 0.09 & 1.75 & 0.89 & 0.44 & 3.32 & 3.75 & 88.00 & 8.00 \\
\hline $0.20-0.40$ & 24.18 & 6.40 & 38.00 & 0.11 & 1.56 & 0.92 & 1.21 & 2.95 & 4.16 & 72.00 & 8.75 \\
\hline $0.20-0.40$ & 36.27 & 6.10 & 10.00 & 0.13 & 1.35 & 0.88 & 1.26 & 2.67 & 3.93 & 68.00 & 7.00 \\
\hline $0.20-0.40$ & 48.36 & 6.73 & 23.00 & 0.06 & 1.76 & 1.01 & 0.37 & 3.34 & 3.70 & 91.00 & 8.75 \\
\hline $0.20-0.40$ & 60.45 & 6.48 & 19.00 & 0.10 & 1.61 & 0.94 & 0.88 & 3.11 & 3.99 & 77.00 & 8.50 \\
\hline $0.20-0.40$ & 72.54 & 6.33 & 9.00 & 0.11 & 1.21 & 0.87 & 1.12 & 2.56 & 3.67 & 68.00 & 9.25 \\
\hline CV (\%) & - & 5.32 & 113.83 & 26.47 & 26.47 & 23.66 & 48.73 & 21.56 & 15.90 & 13.21 & 28.78 \\
\hline Mean & - & 6.48 & 18.00 & 0.10 & 1.54 & 0.92 & 0.88 & 2.99 & 3.87 & 77.00 & 8.38 \\
\hline
\end{tabular}

TEB: total exchangeable base; CEC: cation exchange capacity; V: base saturation; OM: organic matter. ${ }^{(1)}$ Considering the total dose applied during the experiment; (2) Mehlich-1 extraction; ${ }^{(3)} \mathrm{KCl} 1 \mathrm{M}$ extraction; ${ }^{(4)}$ modified Walkley \& Black method (Silva et al. 1999). 
Considering the number of viable leaves at flowering reported by Nomura et al. (2013), those obtained here were higher and similar in the first and second production cycles, with averages of 16.1 and 11.5 leaves, respectively. These authors found the same variation in pseudostem height and pseudostem diameter between the first and second production cycles, with average pseudostem height values of 3.5-4.5 $\mathrm{m}$ and pseudostem diameter of $0.25-0.30 \mathrm{~m}$, respectively. The yields were relatively higher or similar to those reported by Roque et al. (2014): 112 and 163.43 fruits for number of fruits per bunch; $0.158 \mathrm{~m}$ and $0.147 \mathrm{~m}$ for average fruit length; $0.385 \mathrm{~m}$ and $0.359 \mathrm{~m}$ for average fruit diameter; $12.26 \mathrm{~kg}$ and $14.29 \mathrm{~kg}$ for banana hand mass; $14.02 \mathrm{~kg}$ and $16.46 \mathrm{~kg}$ for banana bunch mass; $20.42 \mathrm{t} \mathrm{ha}^{-1}$ and $23.81 \mathrm{t} \mathrm{ha}^{-1}$ for relative hand yield; and $23.56 \mathrm{t} \mathrm{ha}^{-1}$ and $27.42 \mathrm{t} \mathrm{ha}^{-1}$ for relative bunch yield, considering the first and second orchard production cycles, respectively.

In relation to the time between transplanting and bunch harvest, a tendency to a shorter time may be observed in the second production cycle, as the humic substances dose is decreased to the minimum point of the quadratic model curve (Figure 1).

According to the adjusted model, the shortest time between transplanting and harvest (735 days) occurred with the application of $13.17 \mathrm{~kg} \mathrm{ha}^{-1}$, with a 43-days decrease, if compared to the control
(778 days). It was found that the averages recorded for transplanting to bunch harvest are very close to those reported by Nomura et al. (2013), who obtained values of $453.4 \pm 19.2$ and $747.1 \pm 27.9$ days for the first and second 'BRS Princesa' cultivation cycles, respectively, without applying humic substances.

The significant effect of humic substances on transplanting to bunch harvest may likely be explained by the stimulating effects, albeit not significant, of humic substances on plant metabolism (Baldotto \& Baldotto 2014, Canellas \& Olivares 2014, Caron et al. 2015). On the other hand, there

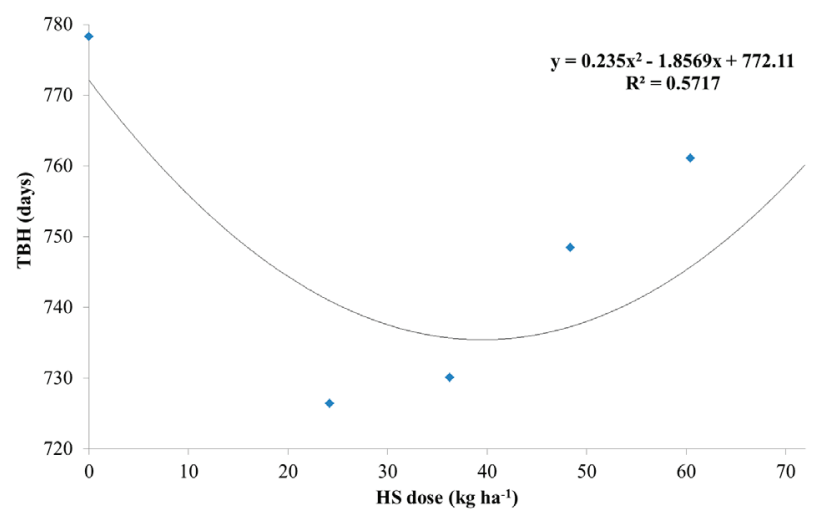

Figure 1. Graphic representation of the quadratic adjustment of the response of time between transplanting and bunch harvest (TBH) to the application of humic substances (HS).

Table 6. Average growth and yield properties, as a function of cycle and total dose applied

\begin{tabular}{|c|c|c|c|c|c|c|c|c|c|c|c|c|c|c|}
\hline \multirow{2}{*}{$\begin{array}{c}\text { Production } \\
\text { cycle }\end{array}$} & \multirow{2}{*}{$\begin{array}{c}\text { Treatment } \\
\mathrm{kg} \mathrm{ha}^{-1}\end{array}$} & $\mathrm{PSH}$ & PSD & \multirow{2}{*}{$\begin{array}{c}\text { NLF } \\
\text { unit }\end{array}$} & \multirow{2}{*}{$\begin{array}{l}\text { TBH } \\
\text { days }\end{array}$} & BBM & $\mathrm{BHM}$ & $\mathrm{BSM}$ & NHB & NFB & AFL & AFD & RBY & RHY \\
\hline & & \multicolumn{2}{|c|}{$-\mathrm{m}-$} & & & & $-\mathrm{kg}$ & + & \multicolumn{2}{|c|}{- unit -} & \multicolumn{2}{|c|}{$-\mathrm{cm}-$} & \multicolumn{2}{|c|}{ - ton $\mathrm{ha}^{-1}$} \\
\hline \multirow{6}{*}{$1^{\text {st }}$} & 0.00 & 3.250 & 0.280 & 10.00 & 460.00 & 17.64 & 15.94 & 1.75 & 8.00 & 123.00 & 15.90 & 3.97 & 34.38 & 31.88 \\
\hline & 13.58 & 3.220 & 0.270 & 10.00 & 446.00 & 16.36 & 14.72 & 1.64 & 8.00 & 118.00 & 15.70 & 3.95 & 32.71 & 29.44 \\
\hline & 20.30 & 3.170 & 0.280 & 10.00 & 435.00 & 16.26 & 14.52 & 1.74 & 8.00 & 112.00 & 15.20 & 3.94 & 32.52 & 29.04 \\
\hline & 27.02 & 3.400 & 0.280 & 9.00 & 433.00 & 15.56 & 13.82 & 1.74 & 7.00 & 107.00 & 16.20 & 3.93 & 31.11 & 27.64 \\
\hline & 33.08 & 3.220 & 0.270 & 10.00 & 423.00 & 16.33 & 14.63 & 1.69 & 8.00 & 116.00 & 15.90 & 4.04 & 32.65 & 29.27 \\
\hline & 40.60 & 3.370 & 0.270 & 10.00 & 442.00 & 16.05 & 14.45 & 1.59 & 8.00 & 116.00 & 16.00 & 3.94 & 32.01 & 28.91 \\
\hline CV (\%) & & 4.630 & 7.750 & 7.70 & 4.00 & 11.21 & 11.44 & 12.16 & 4.68 & 9.48 & 3.59 & 2.58 & 11.21 & 11.44 \\
\hline Mean & & 3.272 & 0.275 & 10.00 & 440.00 & 16.37 & 14.68 & 1.69 & 8.00 & 115.00 & 15.80 & 3.96 & 32.73 & 29.36 \\
\hline \multirow{6}{*}{$2^{\text {nd }}$} & 0.00 & 4.240 & 0.280 & 13.00 & 778.00 & 14.58 & 13.09 & 1.49 & 9.00 & 139.00 & 16.30 & 3.44 & 29.16 & 26.18 \\
\hline & 24.18 & 4.330 & 0.290 & 12.00 & 726.00 & 15.32 & 13.72 & 1.60 & 8.00 & 117.00 & 16.00 & 3.43 & 30.63 & 27.43 \\
\hline & 36.27 & 4.410 & 0.290 & 12.00 & 730.00 & 13.28 & 11.95 & 1.43 & 9.00 & 135.00 & 15.50 & 3.33 & 26.77 & 23.91 \\
\hline & 48.36 & 4.230 & 0.280 & 12.00 & 748.00 & 16.45 & 14.67 & 1.77 & 9.00 & 150.00 & 16.40 & 3.47 & 32.90 & 29.35 \\
\hline & 60.45 & 4.360 & 0.290 & 12.00 & 761.00 & 15.27 & 13.71 & 1.56 & 9.00 & 142.00 & 15.80 & 3.40 & 30.54 & 27.41 \\
\hline & 72.54 & 4.210 & 0.280 & 12.00 & 748.00 & 14.52 & 13.11 & 1.41 & 9.00 & 142.00 & 15.00 & 3.35 & 29.05 & 26.22 \\
\hline CV (\%) & & 4.840 & 9.530 & 3.82 & 2.23 & 10.62 & 10.71 & 14.79 & 6.22 & 9.36 & 4.10 & 2.26 & 10.62 & 10.71 \\
\hline Mean & & 4.297 & 0.285 & 12.00 & 749.00 & 14.90 & 13.37 & 1.54 & 9.00 & 137.00 & 15.80 & 3.40 & 29.84 & 26.75 \\
\hline
\end{tabular}


is no consensus regarding the mechanisms of action of these organic acids, given the varied responses of plants with concentration, molecular weight, organic acid structure and sources of humic substances, in addition to variations by plant species (Lodhi et al. 2013, Muscolo et al. 2013, Zandonadi et al. 2013, Caron et al. 2015).

The results of the present study demonstrate the need for additional researches that assess the effect of fertigation with high doses of humic substances, considering different sources such as coal, peat, humus, plant and animal waste. Other aspects that need to be elucidated are the ideal concentration of injection and frequency and application time per plant species, as well as soil type.

\section{CONCLUSIONS}

1. There was no effect of the humic substances doses evaluated on the chemical attributes of a Dystric Densic Xantic Ferralsol;

2. The application of humic substances did not interfere with the agronomic performance of the 'BRS Princesa' banana trees in either production cycle.

\section{ACKNOWLEDGMENTS}

To the Coordenação de Aperfeiçoamento de Pessoal de Nível Superior (Capes) and Fundação de Amparo à Pesquisa do Estado da Bahia (Fapesb), for the financial assistance, and to the Centro Nacional de Pesquisa de Mandioca e Fruticultura Tropical, for the technical support and facilities provided to conduct the study.

\section{REFERENCES}

ALLEN, R. G. et al. Crop evapotranspiration: guidelines for computing crop water requirements. Rome: FAO, 1998.

ALVES, E. J. et al. Tratos culturais e colheita. In: BORGES, A. L.; SOUZA, L. S. O cultivo da bananeira. Cruz das Almas: Embrapa Mandioca e Fruticultura, 2004. p. 32-44.

ARJUMEND, T.; ABBASI, M. K.; RAFIQUE, E. Effects of lignite-derived humic acid on some selected soil properties, growth and nutrient uptake of wheat (Triticum aestivum L.) grown under greenhouse conditions. Pakistan Journal of Botany, v. 47, n. 6, p. 2231-2238, 2015.

BALdotto, M. A.; BALdotTo, L. E. B. Ácidos húmicos. Revista Ceres, v. 61, suppl., p. 856-881, 2014.
BEZERRA, P. S. S.; PRADO, R. M.; SHIGAKI, F. Natural phosphate and humic substances applied in quartzipsamment and kandiudult cultivated with sugar cane. Journal of Agriculture and Environmental Sciences, v. 4, n. 2, p. 153-163, 2015.

BORGES, A. L.; SOUZA, L. S. (Orgs.). Recomendações de calagem e adubação para abacaxi, acerola, banana, laranja, tangerina, lima ácida, mamão, mandioca, manga e maracujá. Cruz das Almas: Embrapa Mandioca e Fruticultura Tropical, 2009.

CANELlAS, L. P.; OLIVARES, F. L. Physiological responses to humic substances as plant growth promoter. Chemical and Biological Technologies in Agriculture, v. 1, n. 1, p. 3-10, 2014.

CARON, V. C. et al. Condicionadores do solo: ácidos húmicos e fúlvicos. Piracicaba: ESALQ/USP, 2015.

COELHO, E. F. et al. Produtividade da bananeira 'PrataAnã' e 'Grande Naine' no terceiro ciclo sob irrigação por microaspersão em tabuleiros costeiros da Bahia. Revista Brasileira de Fruticultura, v. 28, n. 3, p. 435-438, 2006.

COELHO, E. F. et al. Roots of 'BRS Princesa' banana fertigated with humic substances and saponin-based plant extracts. Acta Scientiarum Agronomy, v. 38, n. 4, p. 521528, 2016.

EMPRESA BRASILEIRA DE PESQUISA AGROPECUÁRIA (Embrapa). Manual de métodos de análises de solos. 2. ed. Rio de Janeiro: Embrapa Solos, 2011.

HARTZ, T. K.; BOTTOMS, T. G. Humic substances generally ineffective in improving vegetable crop nutrient uptake or productivity. HortScience, v. 45, n. 6, p. 906910, 2010.

IUSS WORKING GROUP WRB. World Reference Base for Soil Resources. World soil resources reports. Rome: FAO, 2014.

JONES, C. A.; JACOBSEN, J. S.; MUGAAS, A. Effect of low-rate commercial humic acid on phosphorus availability, micronutrient uptake, and spring wheat yield. Communications in Soil Science and Plant Analysis, v. 38, n. 7-8, p. 921-933, 2007.

LITTLE, K. R. et al. Do lignite-derived organic amendments improve early-stage pasture growth and key soil biological and physicochemical properties? Crop and Pasture Science, v. 65, n. 9, p. 899-910, 2014.

LODHI, A. et al. Characterization of commercial humic acid samples and their impact on growth of fungi and plants. Soil \& Environment, v. 32, n. 1, p. 63-70, 2013.

LÓPEZ, C. (Ed.). Fertirrigación: cultivos hortícolas, frutales y ornamentales. Madri: Mundi-Prensa Libros, 2005. 
MAHMOUD, A. R.; HAFEZ, M. M. Increasing productivity of potato plants (Solanum tuberosum L.) by using potassium fertilizer and humic acid application. International Journal of Academic Research, v. 2, n. 2, p. 83-88, 2010.

MBAGWU, J. S. C.; PICCOLO, A. Changes in soil aggregate stability induced by amendment with humic substances. Soil Technology, v. 2, n. 1, p. 49-57, 1989.

MUSCOLO, A.; SIDARI, M.; NARDI, S. Humic substance: relationship between structure and activity. Journal of Geochemical Exploration, v. 129, suppl., p. 57-63, 2013.

NOMURA, E. S. et al. Aclimatização de mudas micropropagadas de bananeira 'Grand Naine' com aplicação de biofertilizantes em duas estações do ano. Revista Ceres, v. 59, n. 4, p. 518-529, 2012.

NOMURA, E. S. et al. Avaliação agronômica de genótipos de bananeiras em condições subtropicais, Vale do Ribeira, São Paulo - Brasil. Revista Brasileira de Fruticultura, v. 35, n. 1, p. 112-122, 2013.

PRIMO, D. C.; MENEZES, R. S. C.; SILVA, T. O. Substâncias húmicas da matéria orgânica do solo: uma revisão de técnicas analíticas e estudos no Nordeste brasileiro. Scientia Plena, v. 7, n. 5, p. 1-13, 2011.

ROQUE, R. L. et al. Desempenho agronômico de genótipos de bananeira no Recôncavo da Bahia. Revista Brasileira de Fruticultura, v. 36, n. 3, p. 598-609, 2014.

RUSSO, R. et al. Efecto de un bioestimulante húmico extraído del raquis de banano (Pinzote) sobre el crecimiento de plántulas de banano (Musa AAA subgrupo "Cavendish" clon'Gran enano). Agronomía Mesoamericana, v. 6, n. 1, p. $130-133,1995$.
SANTOS, G. A. et al. Fundamentos da matéria orgânica: ecossistemas tropicais e subtropicais. 2. ed. Porto Alegre: Metrópole, 2008.

SANTOS, H. G. et al. (Eds.). Sistema brasileiro de classificação de solos. 3. ed. rev. ampl. Brasília, DF: Embrapa, 2013.

SELIM, E. M.; EL-NEKLAWY, A. S.; EL-ASHRY, S. M. Beneficial effects of humic substances on soil fertility to fertigated potato grown on sandy soil. Libyan Agriculture Research Center Journal International, v. 1, n. 4, p. $255-$ 262, 2010.

SELIM, E.; MOSA, A. Fertigation of humic substances improves yield and quality of broccoli and nutrient retention in a sandy soil. Journal of Plant Nutrition and Soil Science, v. 175, n. 2, p. 273-281, 2012.

SEYEDBAGHERI, M. Influence of humic products on soil health and potato production. Potato Research, v. 53, n. 4, p. 341-349, 2010.

SILVA, A. C.; TORRADO, P. V.; ABREU JUNIOR, J. S. Métodos de quantificação da matéria orgânica do solo. Revista da Universidade de Alfenas, v. 5, n. 1, p. 21-26, 1999.

ZANDONADI, D. B. et al. Plant physiology as affected by humified organic matter. Theoretical and Experimental Plant Physiology, v. 25, n. 1, p. 13-25, 2013.

ZHANG, L. et al. Optimal combination of chemical compound fertilizer and humic acid to improve soil and leaf properties, yield and quality of apple (Malus domestica) in the loess plateau of China. Pakistan Journal of Botany, v. 45, n. 4, p. 1315-1320, 2013. 